\title{
A FURTHER STUDY OF A-B-O BLOOD GROUPS AND DIFFERENTIAL FERTILITY AMONG WOMEN IN TWO AUSTRALIAN MATERNITY HOSPITALS
}

\author{
BY \\ R. L. KIRK AND J. W. SHIELD, \\ Department of Zoology, University of Western Australia, \\ N. S. STENHOUSE, \\ Division of Mathematical Statistics, Commonwealth Scientific and Industrial Research Organization, \\ LUCY M. BRYCE AND RACHEL JAKOBOWICZ \\ Australian Red Cross Blood Transfusion Service (Victorian Division) and the Queen Victoria Hospital, Melbourne
}

Two previous reports have examined certain aspects of the problem of incompatibility between mother and child with respect to the A-B-O blood groups for samples drawn from Australian Maternity hospitals. In the first of these, Bryce and others (1950) examined the mother-child blood-group combinations for 7,909 women confined in the Queen Victoria Hospital, Melbourne, during the years 1944-48. In certain mother-child combinations they observed striking differences from expectation. These differences were significant for the excess over expectation of group A infants born to group B mothers, and for the deficiency of group AB infants born to group A mothers. There was also a marked, but not significant, deficiency of group $\mathbf{A}$ infants to group $\mathbf{O}$ mothers. The analysis suggested also the possibility that $\mathrm{AB}$ women are more fertile than women belonging to other blood groups.

The second study, by Kirk and others (1953), examined the pregnancy experience of women of different blood groups confined in the King Edward Memorial Hospital, Perth, during the years 1948-51. A polynomial function fitted to the difference in the average number of pregnancies between women of group $\mathbf{O}$ and group $\mathbf{A}$ for each year of age from 16-40 showed a significant excess of pregnancies in group A women between the ages of 25 and 35, with a tendency for group $O$ women to equal or surpass group A women over the age of 35 . These authors suggested that the excess of pregnancies in group A women in the decade centred in age 30 might be due to the selective loss of children to group $\mathbf{O}$ women in incompatible mating groups, and that group $\mathbf{O}$ women in compatible mating groups are more fertile, and their child-bearing activities more prolonged than those of group A women.

Since these reports were published, we have been able to add further material to both the Melbourne and Perth samples. These cities differ appreciably in size and social structure, and the reproductive patterns of the women in the two samples are significantly different. We thought it desirable therefore to analyse this extended material so that similarities and differences would be emphasized. Certain information was not always available for both samples for the whole of the period under study. In addition the heavy immigration of nonEnglish people into Australia during the post-war years has introduced a heterogeneity into the samples for which due allowance must be made if errors in deduction are to be avoided. Despite these difficulties, however, the results recorded below indicate the value of this type of analysis in studying the effects of blood-group incompatibility on pregnancy experience.

\section{Methods}

The source of the samples, and the techniques of collecting data and determining blood-groups have been given in detail by Bryce and others (1950) and Kirk and others (1953). In addition to the samples analysed in these two papers, 8,423 women were added to the Melbourne sample and 3,831 women added to the Perth sample during the years 1952 and 1953 . The complete Melbourne sample therefore comprises 16,332 confinements for the years 1944-48 and 1952-53, the corresponding figure for the Perth sample being 9,952 confinements during the 6 years 1948-53. 


\section{RESULTS}

(1) Differences in Composition of Samples.The Melbourne 1944-48 and the Perth 1948-51 samples have been analysed in detail previously (Bryce and others, 1950; Kirk and others, 1953). No information was available for the earlier Melbourne sample with respect to mother's age or parity, and whether she was of English or nonEnglish name. Tables I-III give the basic data for

TABLE I

COMPOSITION OF THE 1952-53 SAMPLES FOR MELBOURNE AND PERTH

\begin{tabular}{|c|c|c|c|c|c|c|c|c|}
\hline \multirow[b]{2}{*}{$\begin{array}{l}\text { Blood } \\
\text { Group } \\
\text { of } \\
\text { Mother }\end{array}$} & \multicolumn{4}{|c|}{ Melbourne } & \multicolumn{4}{|c|}{ Perth } \\
\hline & $\begin{array}{l}\text { Single } \\
\text { Births }\end{array}$ & $\underset{\text { Births }}{\text { Twin }}$ & $\begin{array}{c}\text { Rank } \\
\text { and } \\
\text { Age } \\
\text { not } \\
\text { Stated }\end{array}$ & Total & $\begin{array}{l}\text { Single } \\
\text { Births }\end{array}$ & $\begin{array}{c}\text { Twin } \\
\text { Births }\end{array}$ & $\begin{array}{c}\text { Rank } \\
\text { and } \\
\text { Age } \\
\text { not } \\
\text { Stated }\end{array}$ & Total \\
\hline $\mathbf{O}$ & 3,741 & 54 & 118 & 3,913 & 1,780 & 20 & - & 1,800 \\
\hline $\mathbf{A}$ & 3,202 & 31 & 102 & 3,335 & 1,505 & 18 & - & 1,523 \\
\hline B & 801 & 11 & 38 & 850 & 396 & 6 & - & 402 \\
\hline AB & 306 & 4 & 15 & 325 & 104 & 2 & - & 106 \\
\hline All & 8,050 & 100 & $273^{*}$ & 8,423 & 3,785 & 46 & - & 3,831 \\
\hline
\end{tabular}

* Five of these cases had no age stated, but pregnancy rank was recorded. They have been included in the single birth analysis by rank. the 1952 and 1953 sample for both Melbourne and Perth.

In both Melbourne and Perth samples there is a highly significant difference in the blood-group distributions for women of English and non-English name $\left(\chi^{2}=23.857\right.$ and 26.081 respectively for 3 d.f.). There is no dignificant difference for the English name samples between Melbourne and Perth $\left(\chi^{2}=7 \cdot 0093 d-f\right)$, or for the non-English name samples $\left(\chi^{2}=3.8333 d-f\right)$.

Although the blood-group frequencies for women of English name are not significantly different in the two samples, there is a significant difference in the age distribution of women entering the two hospitals (Table III, $\chi^{2}=33.878$ on $4 d-f$ ). The same is true also for women of non-English name $\left(\chi^{2}=23 \cdot 316\right.$ on $4 d-f)$. For the English name sample the difference is due largely to the increased number of young mothers in Perth. The women of non-English name are significantly older in the two samples than those of English name. This is readily understood, since many of them are recent immigrants to Australia and their reproductive experience has been more seriously interfered with by war and its aftermath than is the case for the women of English name. Most of the latter have been resident in Australia since birth. (The validity of this statement has been

TABLE II

DISTRIBUTION OF ABO BLOOD GROUPS AMONG MOTHERS OF ENGLISH AND NON-ENGLISH NAME IN TWO AUSTRALIAN MATERNITY HOSPITAL SAMPLES

\begin{tabular}{|c|c|c|c|c|c|c|c|c|c|c|c|c|}
\hline \multirow{3}{*}{$\begin{array}{l}\text { Blood } \\
\text { Group }\end{array}$} & \multicolumn{6}{|c|}{ Melbourne, 1952 and 1953} & \multicolumn{6}{|c|}{ Perth, 1952 and 1953} \\
\hline & \multicolumn{2}{|c|}{ English Name } & \multicolumn{2}{|c|}{ Non-English Name } & \multicolumn{2}{|c|}{ Total Sample } & \multicolumn{2}{|c|}{ English Name } & \multicolumn{2}{|c|}{ Non-English Name } & \multicolumn{2}{|c|}{ Total Sample } \\
\hline & No. & Per cent. & No. & Per cent. & No. & Per cent. & No. & Per cent. & No. & Per cent. & No. & Per cent. \\
\hline $\begin{array}{c}\mathbf{O} \\
\mathbf{A} \\
\mathbf{B} \\
\mathbf{A B}\end{array}$ & $\begin{array}{r}3,196 \\
2,697 \\
632 \\
244\end{array}$ & $\begin{array}{r}47 \cdot 22 \\
39 \cdot 84 \\
9 \cdot 34 \\
3 \cdot 60\end{array}$ & $\begin{array}{r}599 \\
536 \\
180 \\
66\end{array}$ & $\begin{array}{r}43 \cdot 37 \\
38 \cdot 81 \\
13 \cdot 04 \\
4 \cdot 78\end{array}$ & $\begin{array}{r}3,795 \\
3,233 \\
812 \\
310\end{array}$ & $\begin{array}{r}46 \cdot 56 \\
39.67 \\
9.96 \\
3.80\end{array}$ & $\begin{array}{r}1,384 \\
1,153 \\
262 \\
74\end{array}$ & $\begin{array}{r}48 \cdot 17 \\
40 \cdot 13 \\
9 \cdot 12 \\
2 \cdot 58\end{array}$ & $\begin{array}{r}416 \\
370 \\
140 \\
32\end{array}$ & $\begin{array}{r}43 \cdot 42 \\
38 \cdot 62 \\
14 \cdot 61 \\
3 \cdot 34\end{array}$ & $\begin{array}{r}1,800 \\
1,523 \\
402 \\
106\end{array}$ & $\begin{array}{r}46 \cdot 99 \\
39 \cdot 75 \\
10 \cdot 49 \\
2 \cdot 77\end{array}$ \\
\hline All Groups & 6,769 & $100 \cdot 00$ & 1,381 & $100 \cdot 00$ & 8,150 & $99 \cdot 99$ & 2,873 & $100 \cdot 00$ & 958 & $99 \cdot 99$ & 3,831 & $100 \cdot 00$ \\
\hline
\end{tabular}

TABLE III

AGE DISTRIBUTION OF MOTHERS OF ENGLISH AND NON-ENGLISH NAME IN TWO AUSTRALIAN MATERNITY HOSPITAL SAMPLES

\begin{tabular}{|c|c|c|c|c|c|c|c|c|c|c|c|c|}
\hline \multirow{3}{*}{$\underset{\text { (yrs) }}{\text { Age }}$} & \multicolumn{6}{|c|}{ Melbourne, 1952 and 1953} & & & \multicolumn{4}{|c|}{ Perth, 1952 and 1953} \\
\hline & \multicolumn{2}{|c|}{ English Name } & \multicolumn{2}{|c|}{ Non-English Name } & \multicolumn{2}{|c|}{ Total Sample } & \multicolumn{2}{|c|}{ English Name } & \multicolumn{2}{|c|}{$\overline{\text { Non-English Name }}$} & \multicolumn{2}{|c|}{ Total Sample } \\
\hline & No. & Per cent. & No. & Per cent. & No. & Per cent. & No. & Per cent. & No. & Per cent. & No. & Per cent. \\
\hline $\begin{array}{l}20 \text { and } \\
\text { under } \\
21-25 \quad \ldots \\
26-30 \quad \ldots \\
31-35 \quad \ldots \\
36 \text { and over }\end{array}$ & $\begin{array}{r}1,094 \\
2,492 \\
1,780 \\
919 \\
484\end{array}$ & $\begin{array}{r}16 \cdot 16 \\
36 \cdot 81 \\
26 \cdot 30 \\
13 \cdot 58 \\
7 \cdot 15\end{array}$ & $\begin{array}{r}158 \\
488 \\
454 \\
200 \\
81\end{array}$ & $\begin{array}{r}11 \cdot 44 \\
35 \cdot 34 \\
32 \cdot 87 \\
14 \cdot 48 \\
5 \cdot 87\end{array}$ & $\begin{array}{r}1,252 \\
2,980 \\
2,234 \\
1,119 \\
565\end{array}$ & $\begin{array}{r}15 \cdot 36 \\
36 \cdot 56 \\
27 \cdot 41 \\
13 \cdot 73 \\
6 \cdot 93\end{array}$ & $\begin{array}{r}581 \\
1,043 \\
666 \\
346 \\
237\end{array}$ & $\begin{array}{r}20 \cdot 22 \\
36 \cdot 30 \\
23 \cdot 18 \\
12 \cdot 04 \\
8 \cdot 25\end{array}$ & $\begin{array}{l}112 \\
279 \\
314 \\
152 \\
101\end{array}$ & $\begin{array}{l}11 \cdot 69 \\
29 \cdot 12 \\
32 \cdot 78 \\
15 \cdot 87 \\
10 \cdot 54\end{array}$ & $\begin{array}{r}693 \\
1,322 \\
980 \\
498 \\
338\end{array}$ & $\begin{array}{r}18 \cdot 09 \\
34 \cdot 51 \\
25 \cdot 58 \\
13 \cdot 00 \\
8 \cdot 82\end{array}$ \\
\hline All Ages .. & 6,769 & $100 \cdot 00$ & 1,381 & $100 \cdot 00$ & 8,150 & $99 \cdot 99$ & 2,873 & 99.99 & 958 & $100 \cdot 00$ & 3,831 & $100 \cdot 00$ \\
\hline
\end{tabular}


checked for a single year in the Perth sample by examining the information recorded on the birth certificates of all babies born in the King Edward Memorial Hospital during 1952*).

Because of the difference in age structure between the two samples we have considered it important to analyse the data from Melbourne and Perth separately.

(2) Mean Number of Pregnancies per Woman.It has been possible to calculate the mean number of pregnancies for women of English name in the Melbourne sample for 1952 and 1953 and in the Perth sample for the whole period 1948-53 (Table IV). In both places women of group $A$ have experienced more pregnancies on the average than group $O$ women. In the Melbourne sample the difference of 0.055 pregnancies per woman is not significant $(t=1 \cdot 271)$ but the difference in Perth of 0.103 pregnancies per women is significant at the 5 per cent. level $(t=2 \cdot 296)$.

TABLE IV

MEAN NUMBER OF PREGNANCIES PER WOMAN IN EACH BLOOD GROUP

(Women of English Name only)

\begin{tabular}{|c|c|c|c|c|c|c|}
\hline \multirow[b]{2}{*}{$\begin{array}{l}\text { Blood } \\
\text { Group }\end{array}$} & \multicolumn{3}{|c|}{ Melbourne, 1952 and 1953} & \multicolumn{3}{|c|}{ Perth, 1948 to 1953} \\
\hline & $\begin{array}{l}\text { No. of } \\
\text { Women }\end{array}$ & $\begin{array}{c}\text { Mean } \\
\text { No. of } \\
\text { Preg- } \\
\text { nancies }\end{array}$ & $\begin{array}{l}\text { S.D. of } \\
\text { Mean }\end{array}$ & $\begin{array}{l}\text { No. of } \\
\text { Women }\end{array}$ & $\begin{array}{c}\text { Mean } \\
\text { No. of } \\
\text { Preg- } \\
\text { nancies }\end{array}$ & $\begin{array}{l}\text { S.D. of } \\
\text { Mean }\end{array}$ \\
\hline $\mathbf{O}$ & 3,196 & $2 \cdot 503$ & 0.029 & 3,711 & $2 \cdot 702$ & 0.030 \\
\hline $\mathbf{A}$ & 2,697 & $2 \cdot 558$ & 0.033 & 3,281 & $2 \cdot 805$ & 0.033 \\
\hline $\mathbf{B}$ & 632 & $2 \cdot 429$ & 0.062 & 755 & $2 \cdot 767$ & 0.069 \\
\hline $\mathbf{A B}$ & 244 & $2 \cdot 508$ & $0 \cdot 108$ & 205 & $2 \cdot 756$ & $0 \cdot 126$ \\
\hline All & 6,769 & $2 \cdot 518$ & 0.020 & 7,952 & $2 \cdot 752$ & 0.021 \\
\hline
\end{tabular}

It is of interest to note that the mean number of pregnancies for $\mathrm{AB}$ women in these two samples is lower than group $\mathbf{A}$ in one and than both group $\mathbf{A}$ and group $B$ in the other. These figures do not lend support therefore to our earlier suggestion (Bryce and others, 1950) that $A B$ women might be more fertile than women ín other blood groups.

(3) Mean Number of Pregnancies for Group $O$ and $A$ Women at Different Ages.-In Table V (opposite) the mean number of pregnancies for group $\mathrm{O}$ and $\mathrm{A}$ women is given for age from 16-40 yrs. If the difference between the means for group $O$ and group A women is plotted, it is possible to fit a curve to the values obtained. For the Perth sample

* We are indebted to the Registrar-General for Western Australia for permission to search his records. the difference tends to increase linearly with age, and in the fitted curve the linear term accounts for the bulk of the variation. Unlike the earlier and smaller Perth sample, there is no longer any apparent tendency for group $\mathrm{O}$ women to compensate over the age of 35 for the clear-cut deficiency in pregnancy experience of group $\mathrm{O}$ women between the ages of 25-35. We can conclude, therefore, that in the Perth 1948-53 sample, women of group A have experienced relatively more pregnancies than group $\mathbf{O}$ women: not only is the difference in the means significant, but the difference increases linearly with age.

A similar analysis applied to the difference in mean number of pregnancies experienced by women of English name of groups $\mathrm{A}$ and $\mathrm{O}$ in the Melbourne 1942-53 sample shows no consistent trend, only the quintic term in the polynomial having any significance. At first this result seems surprising, since the Perth and Melbourne samples are approximately the same size. A more detailed examination of the data in Table $V$ reveals that a trend similar to that present in the Perth sample is present in the earlier age groups, but the variation from year to year above age 35 becomes very great in the Melbourne sample. In fact the polynomial fitted to the differences between group $\mathrm{A}$ and group $\mathrm{O}$ women from age 16 to 33 reveals a significant trend, the linear and quadratic terms accounting for the bulk of the variation. It should be pointed out clearly, however, that even though the trend in pregnancy experience in the younger age groups is the same in both the Melbourne and Perth samples, the difference between group $\mathbf{A}$ and group $\mathbf{O}$ women in Melbourne is never as large as is the case in Perth.

It seems likely that the discrepancy between the analysis for the Perth and Melbourne samples is related to the difference in the overall pregnancy experience of women in the two samples. The Perth women of English name have had 0.23 more pregnancies per woman than the corresponding women in Melbourne, the difference being highly significant $(t=7.97, P<0.001)$. The difference in pregnancy experience between group $O$ and group $A$ women will almost certainly be less marked in the sample with the smaller average number of pregnancies per woman. The importance of bearing in mind the difference in pregnancy experience when comparing the relationship of blood groups to fertility in samples from difference places will be discussed more fully in a later section.

(4) Mother-Child Blood-Group Combinations.For the Melbourne sample the blood-group of the child has been determined in addition to that of the 
TABLE V

MEAN NUMBER OF PREGNANCIES TO GROUP O AND A WOMEN OF ENGLISH NAME ONLY AT DIFFERENT AGES (Melbourne, 1952 and 1953; Perth 1948 to 1953)

\begin{tabular}{|c|c|c|c|c|c|c|c|c|c|c|c|c|c|}
\hline \multirow{3}{*}{\multicolumn{2}{|c|}{$\begin{array}{c}\text { Age of } \\
\text { Mother } \\
\text { (yrs) }\end{array}$}} & \multicolumn{6}{|c|}{ Melbourne, 1952 and 1953} & \multicolumn{6}{|c|}{ Perth, 1948 to 1953} \\
\hline & & \multicolumn{3}{|c|}{ Group O Rh + and - } & \multicolumn{3}{|c|}{ Group A Rh + and - } & \multicolumn{3}{|c|}{ Group O Rh + and - } & \multicolumn{3}{|c|}{ Group A Rh + and - } \\
\hline & & $\begin{array}{l}\text { No. of } \\
\text { Women }\end{array}$ & $\begin{array}{c}\text { No. of } \\
\text { Preg- } \\
\text { nancies }\end{array}$ & $\begin{array}{c}\text { Mean } \\
\text { No. of } \\
\text { Preg- } \\
\text { nancies }\end{array}$ & $\begin{array}{l}\text { No. of } \\
\text { Women }\end{array}$ & $\begin{array}{c}\text { No. of } \\
\text { Preg- } \\
\text { nancies }\end{array}$ & $\begin{array}{c}\text { Mean } \\
\text { No. of } \\
\text { Preg- } \\
\text { nancies }\end{array}$ & $\begin{array}{l}\text { No. of } \\
\text { Women }\end{array}$ & $\begin{array}{c}\text { No. of } \\
\text { Preg- } \\
\text { nancies }\end{array}$ & $\begin{array}{c}\text { Mean } \\
\text { No. of } \\
\text { Preg- } \\
\text { nancies }\end{array}$ & $\begin{array}{l}\text { No. of } \\
\text { Women }\end{array}$ & $\begin{array}{c}\text { No. of } \\
\text { Preg- } \\
\text { nancies }\end{array}$ & $\begin{array}{c}\text { Mean } \\
\text { No. of } \\
\text { Preg- } \\
\text { nancies }\end{array}$ \\
\hline $\begin{array}{l}16 \text { or less } \\
17 \ldots \\
18 \ldots \\
19 \ldots \\
20 \ldots\end{array}$ & $\begin{array}{l}\cdots \\
\cdots \\
\cdots\end{array}$ & $\begin{array}{r}23 \\
70 \\
97 \\
143 \\
197\end{array}$ & $\begin{array}{r}23 \\
77 \\
118 \\
204 \\
304\end{array}$ & $\begin{array}{l}1 \cdot 0000 \\
1 \cdot 1000 \\
1 \cdot 2165 \\
1 \cdot 4266 \\
1 \cdot 5431\end{array}$ & $\begin{array}{r}25 \\
33 \\
78 \\
138 \\
151\end{array}$ & $\begin{array}{r}26 \\
37 \\
94 \\
195 \\
235\end{array}$ & $\begin{array}{l}1 \cdot 0400 \\
1 \cdot 1213 \\
1 \cdot 2051 \\
1 \cdot 4130 \\
1 \cdot 5563\end{array}$ & $\begin{array}{r}33 \\
79 \\
152 \\
233 \\
282\end{array}$ & $\begin{array}{r}37 \\
90 \\
187 \\
319 \\
434\end{array}$ & $\begin{array}{l}1 \cdot 1212 \\
1 \cdot 1392 \\
1 \cdot 2303 \\
1 \cdot 3691 \\
1 \cdot 5390\end{array}$ & $\begin{array}{r}18 \\
73 \\
137 \\
202 \\
255\end{array}$ & $\begin{array}{r}18 \\
77 \\
164 \\
281 \\
409\end{array}$ & $\begin{array}{l}1 \cdot 0000 \\
1 \cdot 0548 \\
1 \cdot 1971 \\
1 \cdot 3911 \\
1 \cdot 6039\end{array}$ \\
\hline \multicolumn{2}{|c|}{20 and under } & 530 & 726 & $1 \cdot 3698$ & 425 & 587 & $1 \cdot 3812$ & 779 & 1,067 & $1 \cdot 3697$ & 685 & 949 & $1 \cdot 3854$ \\
\hline $\begin{array}{ll}21 & \ldots \\
22 & \ldots \\
23 & \ldots \\
24 & \ldots \\
25 & \ldots\end{array}$ & $\begin{array}{l}\cdots \\
\cdots \\
\cdots \\
\cdots\end{array}$ & $\begin{array}{l}232 \\
232 \\
236 \\
247 \\
213\end{array}$ & $\begin{array}{l}396 \\
439 \\
454 \\
516 \\
486\end{array}$ & $\begin{array}{l}1 \cdot 7069 \\
1 \cdot 8922 \\
1 \cdot 9237 \\
2 \cdot 0891 \\
2 \cdot 2817\end{array}$ & $\begin{array}{l}194 \\
202 \\
198 \\
199 \\
207\end{array}$ & $\begin{array}{l}329 \\
394 \\
407 \\
444 \\
481\end{array}$ & $\begin{array}{l}1 \cdot 6959 \\
1 \cdot 9505 \\
2 \cdot 0556 \\
2 \cdot 2312 \\
2 \cdot 3237\end{array}$ & $\begin{array}{l}289 \\
288 \\
260 \\
269 \\
232\end{array}$ & $\begin{array}{l}512 \\
551 \\
576 \\
629 \\
588\end{array}$ & $\begin{array}{l}1 \cdot 7716 \\
1 \cdot 9132 \\
2 \cdot 2154 \\
2 \cdot 3383 \\
2 \cdot 5345\end{array}$ & $\begin{array}{l}247 \\
247 \\
245 \\
221 \\
206\end{array}$ & $\begin{array}{l}465 \\
490 \\
518 \\
543 \\
514\end{array}$ & $\begin{array}{l}1 \cdot 8826 \\
1 \cdot 9838 \\
2 \cdot 1143 \\
2 \cdot 4570 \\
2 \cdot 4951\end{array}$ \\
\hline $21-25$ & . & 1,160 & 2,291 & $1 \cdot 9750$ & 1,000 & 2,055 & $2 \cdot 0550$ & 1,338 & 2,856 & $2 \cdot 1345$ & 1,166 & 2,530 & $2 \cdot 1698$ \\
\hline $\begin{array}{ll}26 & \ldots \\
27 & \ldots \\
28 & \ldots \\
29 & \ldots \\
30 & \ldots\end{array}$ & $\begin{array}{l}\cdots \\
\cdots \\
\cdots \\
\cdots\end{array}$ & $\begin{array}{l}219 \\
191 \\
152 \\
138 \\
133\end{array}$ & $\begin{array}{l}540 \\
504 \\
465 \\
404 \\
440\end{array}$ & $\begin{array}{l}2 \cdot 4658 \\
2 \cdot 6387 \\
3 \cdot 0592 \\
2 \cdot 9275 \\
3 \cdot 3083\end{array}$ & $\begin{array}{l}199 \\
151 \\
127 \\
112 \\
117\end{array}$ & $\begin{array}{l}519 \\
388 \\
386 \\
344 \\
366\end{array}$ & $\begin{array}{l}2 \cdot 6080 \\
2 \cdot 5695 \\
3 \cdot 0394 \\
3 \cdot 0714 \\
3 \cdot 1282\end{array}$ & $\begin{array}{l}219 \\
200 \\
163 \\
144 \\
113\end{array}$ & $\begin{array}{l}597 \\
595 \\
537 \\
465 \\
399\end{array}$ & $\begin{array}{l}2 \cdot 7260 \\
2 \cdot 9750 \\
3 \cdot 2945 \\
3 \cdot 2292 \\
3 \cdot 5310\end{array}$ & $\begin{array}{l}169 \\
172 \\
148 \\
137 \\
126\end{array}$ & $\begin{array}{l}475 \\
518 \\
498 \\
518 \\
511\end{array}$ & $\begin{array}{l}2 \cdot 8107 \\
3 \cdot 0116 \\
3 \cdot 3649 \\
3 \cdot 7810 \\
4 \cdot 0556\end{array}$ \\
\hline $26-30$ & . & 833 & 2,353 & $2 \cdot 8247$ & 706 & 2,003 & $2 \cdot 8371$ & 839 & 2,593 & $3 \cdot 0906$ & 752 & 2,520 & $3 \cdot 3511$ \\
\hline $\begin{array}{ll}31 & \ldots \\
32 & \ldots \\
33 & \ldots \\
34 & \ldots \\
35 & \ldots\end{array}$ & $\begin{array}{l}\cdots \\
\cdots \\
\cdots \\
\cdots\end{array}$ & $\begin{array}{r}110 \\
114 \\
76 \\
72 \\
66\end{array}$ & $\begin{array}{l}383 \\
415 \\
279 \\
266 \\
242\end{array}$ & $\begin{array}{l}3 \cdot 4818 \\
3 \cdot 6404 \\
3 \cdot 6711 \\
3 \cdot 6944 \\
3 \cdot 6667\end{array}$ & $\begin{array}{l}97 \\
93 \\
69 \\
56 \\
47\end{array}$ & $\begin{array}{l}325 \\
306 \\
247 \\
220 \\
167\end{array}$ & $\begin{array}{l}3 \cdot 3505 \\
3 \cdot 2903 \\
3 \cdot 5797 \\
3 \cdot 9286 \\
3 \cdot 5532\end{array}$ & $\begin{array}{r}106 \\
104 \\
79 \\
64 \\
63\end{array}$ & $\begin{array}{l}422 \\
381 \\
328 \\
260 \\
292\end{array}$ & $\begin{array}{l}3 \cdot 9811 \\
3 \cdot 6635 \\
4 \cdot 1519 \\
4 \cdot 0625 \\
4 \cdot 6349\end{array}$ & $\begin{array}{r}105 \\
108 \\
72 \\
65 \\
60\end{array}$ & $\begin{array}{l}413 \\
432 \\
307 \\
312 \\
271\end{array}$ & $\begin{array}{l}3 \cdot 9333 \\
4 \cdot 0000 \\
4 \cdot 2639 \\
4 \cdot 8000 \\
4 \cdot 5167\end{array}$ \\
\hline $31-35$ & . & 438 & 1,585 & $3 \cdot 6187$ & 362 & 1,265 & $3 \cdot 4945$ & 416 & 1,683 & $4 \cdot 0457$ & 410 & 1,735 & $4 \cdot 2317$ \\
\hline $\begin{array}{l}36 \ldots \\
37 \ldots \\
38 \ldots \\
39 \ldots \\
40 \text { and ove }\end{array}$ & $\begin{array}{l}\cdots \\
\cdots \\
\cdots\end{array}$ & $\begin{array}{l}61 \\
44 \\
41 \\
36 \\
53\end{array}$ & $\begin{array}{l}252 \\
183 \\
157 \\
182 \\
277\end{array}$ & $\begin{array}{l}4 \cdot 1311 \\
4 \cdot 1591 \\
3 \cdot 8293 \\
5 \cdot 0556 \\
5 \cdot 2264\end{array}$ & $\begin{array}{l}43 \\
42 \\
37 \\
15 \\
67\end{array}$ & $\begin{array}{r}169 \\
198 \\
172 \\
58 \\
396\end{array}$ & $\begin{array}{l}3 \cdot 9302 \\
4 \cdot 7143 \\
4 \cdot 6487 \\
3 \cdot 8667 \\
5 \cdot 9104\end{array}$ & $\begin{array}{r}74 \\
51 \\
56 \\
42 \\
116\end{array}$ & $\begin{array}{l}347 \\
263 \\
275 \\
235 \\
711\end{array}$ & $\begin{array}{l}4 \cdot 6892 \\
5 \cdot 1569 \\
4 \cdot 9107 \\
5 \cdot 5952 \\
6 \cdot 1293\end{array}$ & $\begin{array}{l}53 \\
59 \\
53 \\
30 \\
73\end{array}$ & $\begin{array}{l}269 \\
305 \\
273 \\
180 \\
438\end{array}$ & $\begin{array}{l}5 \cdot 0755 \\
5 \cdot 1695 \\
5 \cdot 1509 \\
6 \cdot 0000 \\
6 \cdot 0000\end{array}$ \\
\hline 36 and ove & & 235 & 1,051 & $4 \cdot 4723$ & 204 & 993 & $4 \cdot 8676$ & 339 & 1,831 & $5 \cdot 4012$ & 268 & 1,465 & $5 \cdot 4664$ \\
\hline All Ages & . & 3,196 & 8,006 & $2 \cdot 5050$ & 2,697 & 6,903 & $2 \cdot 5595$ & 3,711 & 10,030 & $2 \cdot 7028$ & 3,281 & 9,199 & $2 \cdot 8037$ \\
\hline
\end{tabular}

mother, and we have been able to construct a Table showing the A-B-O mother-child combinations for 16,179 single births which occurred to women of English and non-English name during the period
1944-48 and 1952-53 (Table VI). The expected number of children for each combination was calculated by assuming that the mothers were mated at random with a sample of fathers having the same

TABLE VI

MOTHER-CHILD COMBINATIONS IN MELBOURNE SAMPLE 1944-48 + 1952-53. (SINGLE BIRTHS ONLY)

\begin{tabular}{|c|c|c|c|c|c|c|c|c|c|}
\hline \multirow{2}{*}{\multicolumn{5}{|c|}{ Blood Group of Children }} & \multicolumn{5}{|c|}{ Blood Group of Mothers } \\
\hline & & & & & $\mathbf{O}$ & $\mathbf{A}$ & B & $\mathbf{A B}$ & All Groups \\
\hline \multirow{4}{*}{$\begin{array}{l}\text { No. of } \\
\text { Children }\end{array}$} & $\mathbf{O}$ & $\begin{array}{l}\text { (observed) } \\
\text { (estimated) }\end{array}$ & $\begin{array}{l}\cdots \\
\cdots\end{array}$ & $\begin{array}{l}\cdots \\
\cdots\end{array}$ & $\begin{array}{l}5,334 \\
(5,172 \cdot 32)\end{array}$ & $\begin{array}{l}1,879 \\
(1,862 \cdot 30)\end{array}$ & $\begin{array}{l}539 \\
(529 \cdot 77)\end{array}$ & & $\begin{array}{l}7,752 \\
(7,564 \cdot 39)\end{array}$ \\
\hline & $\mathbf{A}$ & $\begin{array}{l}\text { (observed) } \\
\text { (estimated) }\end{array}$ & $\begin{array}{l}\cdots \\
\cdots\end{array}$ & $\begin{array}{l}\cdots \\
\cdots\end{array}$ & $\begin{array}{c}1,754 \\
(1,862 \cdot 30)\end{array}$ & $\begin{array}{l}4,124 \\
(4,115 \cdot 30)\end{array}$ & $\begin{array}{l}218 \\
(190 \cdot 75)\end{array}$ & $\begin{array}{l}273 \\
(259 \cdot 42)\end{array}$ & $\begin{array}{l}6,369 \\
(6,427 \cdot 77)\end{array}$ \\
\hline & B & $\begin{array}{l}\text { (observed) } \\
\text { (estimated) }\end{array}$ & $\begin{array}{l}\cdots \\
\cdots\end{array}$ & $\begin{array}{l}\cdots \\
\cdots\end{array}$ & $\begin{array}{l}497 \\
(529 \cdot 77)\end{array}$ & $\begin{array}{l}218 \\
(190 \cdot 75)\end{array}$ & $\begin{array}{l}681 \\
(698 \cdot 11)\end{array}$ & $\begin{array}{l}226 \\
(210 \cdot 28)\end{array}$ & $\begin{array}{l}1,622 \\
(1,628 \cdot 92)\end{array}$ \\
\hline & AB & $\begin{array}{l}\text { (observed) } \\
\text { (estimated }\end{array}$ & $\ddot{x}$ & $\begin{array}{l}\cdots \\
\cdots\end{array}$ & & $\begin{array}{l}185 \\
(259 \cdot 42)\end{array}$ & $\begin{array}{l}167 \\
(210 \cdot 28)\end{array}$ & $\begin{array}{l}84 \\
(88 \cdot 22)\end{array}$ & $\begin{array}{l}436 \\
(557 \cdot 92)\end{array}$ \\
\hline All Groups & & $\begin{array}{l}\text { (observed) } \\
\text { (estimated) }\end{array}$ & $\begin{array}{l}\cdots \\
\cdots\end{array}$ & $\begin{array}{l}. \\
\cdots\end{array}$ & $\begin{array}{l}7,585 \\
(7,564 \cdot 39)\end{array}$ & $\begin{array}{l}6,406 \\
(6,427 \cdot 77)\end{array}$ & $\begin{array}{l}1,605 \\
(1,628 \cdot 91)\end{array}$ & $\begin{array}{l}583 \\
(557 \cdot 92)\end{array}$ & $\begin{array}{l}16,179 \\
(16,178 \cdot 99)\end{array}$ \\
\hline
\end{tabular}


blood-group distribution as the mothers. In the absence of information on the real blood-group distribution of the fathers this assumption seems to be the most reasonable one to adopt.

There is a theoretical objection to this pooling of the results for the English and non-English name samples. The expectations calculated by using the gene frequencies from the total sample will be different from the expectations derived from the gene frequencies of the English and non-English name groups treated as separate isolates. We have carried out the calculations for the 1952 and 1953 sample by using both the gene frequencies calculated separately for the women of English and non-English name and gene frequencies based on the pooled sample. The difference between the expected numbers obtained by these two methods is approximately $0 \cdot 1$ per cent. We consider, therefore, that the errors introduced by using gene frequencies based on the total sample for 1944-48 and 1952-53 will be rather less than 0.1 per cent., if the other assumption on the gene frequency of the fathers is valid. The gene frequencies have been calculated by the method of maximum likelihood (Stevens, 1938), and the values finally used were $p=0 \cdot 246,193, q=0 \cdot 070,035$, and $r=0 \cdot 683,772$.

A comparison of the observed and expected values reveals discrepancies of the kind noted in our earlier paper (Bryce and others, 1950). The $\chi$ values for each compartment of Table VI are given in Table VII. From this it will be seen that there are significant deficiencies of group $A$ children to group $O$ mothers, and of group AB children to both group $A$ and $B$ mothers. There are also significant excesses of group $\mathbf{O}$ children to group $\mathbf{O}$ mothers, of group B children to group A mothers, and of group A children to group B mothers. The direct evaluation of the mother-infant blood-group relationship of all 16,179 cases examined also reveals a highly significant difference $\left(\chi^{2}=23 \cdot 22 ; P<0 \cdot 001\right)$.

TABLE VII

\begin{tabular}{|c|c|c|c|c|c|}
\hline \multirow{2}{*}{$\begin{array}{l}\text { Blood } \\
\text { Group of } \\
\text { Children }\end{array}$} & \multicolumn{5}{|c|}{ Blood Group of Mothers } \\
\hline & $\mathbf{O}$ & $\mathbf{A}$ & B & $\mathbf{A B}$ & All Groups \\
\hline $\mathbf{O}$ & $+2 \cdot 248$ & $+0 \cdot 387$ & +0.401 & & $+2 \cdot 157$ \\
\hline $\mathbf{A}$ & $-2 \cdot 510$ & $+0 \cdot 136$ & +1.973 & +0.843 & -0.733 \\
\hline B & $-1 \cdot 424$ & +1.973 & -0.648 & $+1 \cdot 084$ & $-0 \cdot 171$ \\
\hline $\mathbf{A B}$ & & $-4 \cdot 621$ & $-2 \cdot 985$ & -0.450 & $-5 \cdot 162$ \\
\hline
\end{tabular}

If the discrepancies noted above are due to the selective action of immune antibodies reacting with foetal tissues we might expect the distribution of mother-child combinations to be different for first-born, second-born, third-born children, etc. This can be investigated for single births in the Melbourne 1952-53 sample. If the number of group $\mathbf{A}$ and $\mathbf{B}$ children to group $\mathbf{O}$ mothers is compared with the group $O$ children to group $A$ and B mothers respectively (Table VIII), it will be seen that there is no deficiency in the former case for first-born children. There is, however, a marked deficiency for second- and third-born group A and B children to group $\mathbf{O}$ mothers when compared with second- and third-born group $O$ children to group $A$ and $B$ mothers, though the difference disappears again for the fourth and higher-born children. The expected number of each birth rank has been calculated using the gene frequencies based on the total mother sample. A comparison of the observed and expected values for each birth rank in each motherchild combination confirms the conclusions reached above which were based on direct comparisons within the body of the Table.

TABLE VIII

MOTHER-CHILD COMBINATIONS BY BIRTH RANK IN MELBOURNE SAMPLE 1952-53 (Single Births only)

\begin{tabular}{|c|c|c|c|c|c|c|}
\hline \multirow{2}{*}{$\begin{array}{c}\text { Blood } \\
\text { Group } \\
\text { of } \\
\text { Children }\end{array}$} & \multirow{2}{*}{ Birth Rank } & \multicolumn{5}{|c|}{ Blood Group of Mothers } \\
\hline & & $\mathbf{O}$ & $\mathbf{A}$ & B & $\mathbf{A B}$ & $\underset{\text { Groups }}{\text { All }}$ \\
\hline $\mathbf{O}$ & 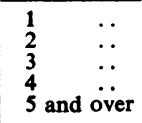 & $\begin{array}{l}881 \\
754 \\
475 \\
269 \\
278\end{array}$ & $\begin{array}{r}287 \\
272 \\
187 \\
92 \\
106\end{array}$ & $\begin{array}{l}81 \\
90 \\
52 \\
17 \\
23\end{array}$ & & $\begin{array}{r}1,249 \\
1,116 \\
714 \\
378 \\
407\end{array}$ \\
\hline $\mathbf{A}$ & $\begin{array}{ll}1 & \cdots \\
2 & \cdots \\
3 & \cdots \\
4 & \cdots \\
5 & \text { and } \\
\text { over }\end{array}$ & $\begin{array}{r}287 \\
236 \\
146 \\
92 \\
93\end{array}$ & $\begin{array}{l}649 \\
615 \\
389 \\
196 \\
217\end{array}$ & $\begin{array}{l}40 \\
27 \\
12 \\
11 \\
11\end{array}$ & $\begin{array}{l}53 \\
32 \\
23 \\
17 \\
16\end{array}$ & $\begin{array}{r}1,029 \\
910 \\
570 \\
316 \\
337\end{array}$ \\
\hline B & $\begin{array}{ll}1 & \cdots \\
2 & \cdots \\
3 & \cdots \\
4 & \cdots \\
5 & \text { and over }\end{array}$ & $\begin{array}{l}79 \\
78 \\
33 \\
15 \\
26\end{array}$ & $\begin{array}{l}32 \\
33 \\
17 \\
11 \\
11\end{array}$ & $\begin{array}{r}109 \\
112 \\
65 \\
32 \\
38\end{array}$ & $\begin{array}{l}34 \\
48 \\
23 \\
14 \\
11\end{array}$ & $\begin{array}{r}254 \\
271 \\
138 \\
72 \\
86\end{array}$ \\
\hline AB & $\begin{array}{ll}1 & \ldots \\
2 & \ldots \\
3 & \cdots \\
4 & \cdots \\
5 & \text { and } \\
\text { over }\end{array}$ & & $\begin{array}{r}28 \\
34 \\
12 \\
5 \\
10\end{array}$ & $\begin{array}{r}22 \\
28 \\
13 \\
11 \\
9\end{array}$ & $\begin{array}{r}19 \\
7 \\
7 \\
2 \\
1\end{array}$ & $\begin{array}{l}69 \\
69 \\
32 \\
18 \\
20\end{array}$ \\
\hline $\begin{array}{l}\text { All } \\
\text { Groups }\end{array}$ & $\begin{array}{ll}1 & \ldots \\
2 & \cdots \\
3 & \cdots \\
4 & \cdots \\
5 & \text { and } \\
\text { over }\end{array}$ & $\begin{array}{r}1,247 \\
1,068 \\
654 \\
376 \\
397\end{array}$ & $\begin{array}{l}996 \\
954 \\
605 \\
304 \\
344\end{array}$ & $\begin{array}{r}252 \\
257 \\
142 \\
71 \\
81\end{array}$ & $\begin{array}{r}106 \\
87 \\
53 \\
33 \\
28\end{array}$ & $\begin{array}{r}2,601 \\
2,366 \\
1,454 \\
784 \\
850\end{array}$ \\
\hline$\overline{\text { All Ranks }}$ & $\cdots$ & 3,742 & 3,203 & 803 & 307 & 8,055 \\
\hline
\end{tabular}

These results would suggest that the observed deficiency of group $\mathbf{A}$ and $\mathbf{B}$ children to group $\mathbf{O}$ mothers might well be due to the operation of an immune response mechanism. On the other hand it is interesting to note that the marked deficiency of group $\mathbf{A B}$ infants to both group $\mathbf{A}$ mothers and 
group B mothers is present for first-born children as well as for those of higher rank. Similarly the observed excess of group B children to group A mothers and group A children to group B mothers shows no relationship to birth rank. A larger sample would need to be analysed for any significance to be attached to the discrepancies noted in these latter cases.

\section{Discussion}

The present study of two large samples of mothers from Australian maternity hospitals is of interest for the current discussion of selective action within the ABO blood-group system. This problem has been reviewed recently by Neel (1954) and it is clear that even though nearly 30 years have elapsed since Hirszfeld and Zborowski (1925) first noted the deficiency of group A children in families where the mother is group $\mathbf{O}$ and the father group $\mathbf{A}$ there has still been no satisfactory assessment of all the evidence now available.

Levine (1943) collected evidence which supported Hirszfeld's original view that matings $\mathbf{A}^{\star} \times \mathbf{O}$ 우 produced fewer offspring than reciprocal matings $O \delta$ and $A$ q. Waterhouse and Hogben (1947) in a more detailed study of the same problem arrived at similar conclusions for their $\mathrm{A} \times \mathrm{O}$ matings, though the $\mathrm{B} \times \mathrm{O}$ matings showed a discrepancy opposite to that which would be expected on the basis of selection in incompatible mating groups.

Waterhouse and Hogben's work has been criticized recently by Bennett and Brandt (1954). This criticism rests in part on the heterogeneity of families segregating for group $A$ and $O$ children in the twelve samples included in their survey. Waterhouse and Hogben drew on family studies of ABO bloodgroups carried out in a number of different countries. Matsunaga (1953) has now made a similar study based solely on Japanese material and finds a significant deficiency of children in matings

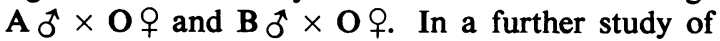
two mining communities in Hokkaido, Matsunaga and Itoh (1954) have demonstrated a highly significant reduction in the number of living children for women in A-B-O incompatible mating groups compared with those in compatible mating groups.

A different approach was made to the problem by Boorman (1950) and by Bryce and others (1950). If group A or B children are being selectively eliminated by group $\mathbf{O}$ mothers, the mother-child combinations for large unselected samples of mothers having babies should reveal deviations from expectation. In both these studies there was no significant deficiency of group A or B children born to group $\mathbf{O}$ mothers, though in the much larger
Australian sample studied by Bryce and others (1950) a marked deficiency was found in group A children to $\mathbf{O}$ mothers. These authors draw attention in their work, however, to much bigger discrepancies, which are present also in Boorman's study, principally the deficiency of group $\mathrm{AB}$ children to $A$ and $B$ mothers, and the excess over expectation of group B children to group A mothers and group $\mathbf{A}$ children to group $\mathbf{B}$ mothers. These two latter discrepancies are difficult to reconcile with the concept of foetal loss through selection in incompatible matings, since both A mother-B child and $B$ mother-A child are incompatible. A somewhat similar study by Johnstone (1954) of an English maternity hospital sample included the blood groups of the fathers as well as of the mothers and children He found no deficiency of group $A$ children in matings $\mathrm{A} \sigma \times \mathrm{O} O$ and points out that if the expectations are distributed in the usual way there is in fact a significant deficiency of group $\mathbf{O}$ children in matings $\mathrm{O} \hat{\sigma} \times \mathrm{A}$ ․ This discrepancy, too, is difficult to reconcile with incompatible selection as ordinarily defined, nor are we yet aware of any clinical or serological evidence which could account for the magnitude of the selective effect stated for the loss of group $O$ children to group A mothers.

Data based on maternity hospital samples of the kind published by Boorman (1950) and Johnstone (1954) must be interpreted with caution when use is made of them for comparison with studies such as those of Waterhouse and Hogben, and Matsunaga. In these latter investigations the material was collected in the main for studies of inheritance of particular genes, so that the proportion of one-child families was low. In both Boorman's and Johnstone's samples, however, the mean number of pregnancies per woman was less than two, approximately 50 per cent. of the mothers being primiparae. If selective action within the ABO blood groups is in any way comparable to that in the $\mathrm{Rh}$ system, very much larger samples than those presented by Boorman and Johnstone would be required to manifest the effects they were looking for if the majority of the women in the sample are experiencing only their first or second pregnancy.

Indeed such information relevant to the question of the influence of incompatibility on pregnancy experience as can be extracted from their published data suggests that selective action is occurring in higher birth-ranks. In Boorman's data the mothers who are classed as incompatible for the $\mathbf{A}$ antigen suffer a marked deficiency in their pregnancy experience above the age of 20 compared with compatible mothers, the difference increasing with age. At age $40-49$ the figures are $2 \cdot 91$ and $3 \cdot 86$. 
Similarly an examination of Table VIa of Johnstone's paper reveals a significant deficiency of mothers experiencing their fourth or higher pregnancy in the mating group $\mathbf{A} \hat{\sigma} \times \mathbf{O} O$ compared with $\mathrm{O} \sigma^{\lambda} \times \mathrm{A}$ \& (for the whole table $\chi^{2}=10 \cdot 392$; 4.d.f.; $0.05>P>0.02$ ).

Our own studies of two Australian maternity hospital samples emphasize the necessity for caution in interpreting samples of this kind. Drawn from two separate populations, the Perth and Melbourne samples are significantly different from one another in age structure and overall pregnancy experience per woman. Using a simple name analysis, both samples can be broken up into an English and non-English name group, there being a highly significant difference in blood-group frequency between the English and non-English name groups for both places. It is possible that the use of more refined techniques could split each of these samples into a still larger number of groups of more homogeneous composition.

A comparison of the English name groups in each sample brings out the following points. Group A women in both samples have experienced slightly more pregnancies than have group $\mathrm{O}$ women. The difference is significant for the Perth sample but not so for Melbourne. A more detailed study of the difference in pregnancy experience by each year of age for group $\mathrm{O}$ and $\mathrm{A}$ women suggests, however, that the tendency for group A women to experience an increasingly large number of pregnancies with increasing age as compared with group $\mathbf{O}$ women is true in Melbourne as well as in Perth. That the differences are much smaller in the Melbourne sample is undoubtedly due to the highly significant difference in pregnancy experience of the women in the two samples.

A comparison of the expected and observed number of children in various mother-child combinations for $\mathrm{ABO}$ blood groups reveals a number of significant discrepancies. The highly significant deficiencies of group $\mathbf{A}$ children to group $\mathbf{O}$ mothers and of group AB children to group A and B mothers supports the hypothesis that mother-child incompatibility is eliminating a proportion of the incompatible children. This simple explanation, however, cannot account for the observed excess of group B children to group A mothers and of group A children to group B mothers. These latter discrepancies still await a satisfactory explanation.

A study of mother-child combinations by birth rank for the Melbourne sample shows no deficiency of group A or B children born to group $\mathbf{O}$ mothers in the first birth rank, but a marked deficiency in the second, and an even greater deficiency in the third.
This study lends support to the concept that a proportion of women of blood group $\mathrm{O}$ progressively suffer a reduction in fertility due to the operation of selection in incompatible pregnancies. Many of the other possibilities related to the general problem of blood group polymorphism in man must await the accumulation of still larger samples before answers approaching the decisive can be given to the questions raised.

\section{SUMMARY}

(1) Two Australian maternity hospital samples have been analysed to throw light on the problem of incompatibility between mother and child within the ABO blood-group system. The first sample comprised mothers entering the Queen Victoria Hospital, Melbourne, during the years 1944-48 and 1952-53. The other sample comprised mothers entering the King Edward VII Maternity Hospital, Perth, during the years 1948-53.

(2) The Melbourne and Perth samples revealed highly significant differences in blood-group distribution between women of English and non-English name, but there were no significant differences in blood-group distribution between the Melbourne and Perth samples for women of English name, or for women of non-English name compared separately. Melbourne and Perth did differ significantly, however, in the age composition and in the overall pregnancy experience of all women in the samples.

(3) In both Melbourne and Perth group A women had a higher average number of pregnancies than group $\mathrm{O}$ women. The difference was significant for Perth but not for Melbourne. The curve fitted to the difference in mean number of pregnancies between the two groups of women for each year of age from 16-40 showed a significant linear increase in the difference group A - group $O$ for Perth. The same trend was present for the Melbourne sample below age 35 , but the greater variability in this sample above that age reduced the significance of the trend over the entire age range studied. The discrepancy between the two samples is due probably to the smaller average number of pregnancies of women in the Melbourne sample.

(4) A comparison of the calculated and observed number of children in different mother-child bloodgroup combinations for 16,179 single births in Melbourne reveals a significant deficiency of group A children to group $\mathbf{O}$ mothers and group $\mathbf{A B}$ children to group A and B mothers, and a significant excess 
of group $\mathbf{O}$ children to group $\mathbf{O}$ mothers, of group $\mathrm{A}$ children to group B mothers, and group B children to group A mothers.

(5) A breakdown of mother-child blood-group combinations by birth rank reveals that the deficiency of group $\mathbf{A}$ and $\mathbf{B}$ children to group $\mathbf{O}$ mothers is absent for first-born children, present for second-born children, and greatest for third-born children.

(6) These results are discussed in relation to other work of a similar kind, and it is suggested that the results presented support the hypothesis that incompatibility between mother and child in the $\mathrm{ABO}$ blood-group system results in selective loss of a proportion of incompatible children.
We should like to thank the medical and nursing staff of the Queen Victoria Hospital for their ready cooperation. We are indebted also to the Medical Superintendent, Dr. A. G. Mathew, and Matron Walsh of the King Edward Memorial Hospital, Perth, for giving us access to their records, to Mrs. B. M. Shield for clerical assistance, and to the Research Grants Committee of the University of Western Australia for financial support.

\section{REFERENCES}

Bennett, J. H., and Brandt, J. (1954). Ann. Eugen., Camb., 18, 302.

Boorman, K. E. (1950). Ibid., 15, 120 .

Bryce, L. M., Jakobowicz, R., McArthur, N., and Penrose, L. S. (1950). Ibid., 15, 271.

Hirszfeld, L., and Zborowski, M. (1925). Klin. Wschr., 1, 1152.

Johnstone, J. M. (1954). British Journal of Preventive and Social Medicine, 8, 117.

Kirk, R. L., Kirk, M., and Stenhouse, N. S. (1953). Ibid., 7, 1.

Levine, P. (1943). J. Hered., 34, 71

Matsunaga, E. (1953). Proc. imp. Acad., Japan, 29, 399.

and Itoh, S. (1954). Ibid., 30, 677.

Neel, J. V. (1954). Amer. J. hum. Genet., 6, 208.

Stevens, W. L. (1938). Ann. Eugen., Camb., 8, 362.

Waterhouse, J. A. H., and Hogben, L. (1947). British Journal of Social Medicine, 1, 1. 
pressure $10 \mathrm{~g} . / \mathrm{mm} .^{2}$ for boys and girls from age 2 years upwards are given for biceps, triceps, subscapular, sub-costal, supra-iliac and abdominal regions. Standard errors at the different ages are also included.

(5) The caliper measurements have been transformed into equivalent actual fat thickness as measured from $x$-ray photographs.

(6) Mean measurements for different nutritional and social groups descend from good to poor nutrition and from high to low social class, but the highest groups in both cases show little difference from the age standards.

(7) The frequency distribution of subcutaneous fat measurements is positively skewed, and it is suggested that this may be partly due to the inclusion of a condition of obesity acting as a separate entity. Research is needed to differentiate over-fat or overthin children on clinical grounds of health and optimal functioning.

(8) Methods of estimating the total quantity of subcutaneous fat in the body from measurements of surface area and a representative set of caliper measurements are being studied.

I should like to express my indebtedness to Drs. W. T. C. Berry and P. J. Cowin for permission to include many of their measurements of body fat in the Table of Norms. I am also most grateful to Dr. J. M. Tanner and Mr. R. Whitehouse for making available the extensive series of comparisons between caliper and $x$-ray measurements obtained during the Harpenden Growth Study from which I calculated the regression equation. Dr. D. A. W. Edwards has also very kindly allowed me to make use of his data on fat measurements in women. From these the National Physical Laboratories calculated the Tables of Correlations which I have analysed. I should also like to acknowledge the help given by Dir. E. R. Bransby in organizing the field trials, and for helpful criticism throughout the investigation.

\section{REFERENCES}

Adcock, E. W., Hammond, W. H., and Magee, H. E. (1947). J. Hyg., 45, 65 .

Berry, W. T. C. (1951). Monthly Bull. Min. Hlth. Lab. Serv., 10, 155. - and Cowin, P. J. (1951). Med. Offr., 85, 213.

- (1954). Brit. J. Nutrit., 8, 79.

Brozek, J., and Keys, A. (1951). Ibid., 5, 194.

Draper, G. (1924). "Human Constitution: a Consideration of its Relationship to Disease", p. 209 et seq. Saunders, Philadelphia.

Du Bois, E. F. (1936). "Basal Metabolisim in Health and Disease", 3rd ed., p. 129. Lea and Febiger, Philadelphia.

Edwards, D. A. W. (1950). Clin. Sci., 9, 259.

- (1955). Voeding, 16, 57.

Wammond, W. H., Healy, M. J. R., Tanner, J. M., and Whitehouse, R. H. (1955). Brit. J. Nutrit., 9, 133.

Freeman, W. (1934). Ann. intern. Med., 7, 805.

Hammond, W. H. (1953a). Hum. Biol., 25, 65.

- (1953b). British Journal of Preventive and Social Medicine, 7, 231

Tanner, J. M. (1955). "Growth at Adolescence". Blackwell, Oxford.

\section{APPENDIX}

\section{Measuring Sites}

Forearm: Lateral surface half-way along.

Forearm: Proximal surface half-way along.

Biceps: Median line over middle of biceps.

Upper Arm: Lateral, midway between acromial edge and olecron.

Triceps: Half-way down the back of the arm over the triceps.

Triceps: Top of triceps.

Sub-scapular: Immediately below inferior angle of scapula following the natural fold at an angle approximately $45^{\circ}$ to the vertical.

Inter-scapular: Between lowest points of scapulae.

Supra-iliac: Immediately above the left iliac crest.

Sub-costal: Immediately under the costal margin vertically below the nipple.

Abdominal: About 1 inch to left of and below umbilicus.

Lower Leg: Lateral, below head of tibia.

Under Chin:

Thigh: Median line 2 in. above patella.

Thigh: Mid-thigh lateral.

Pectoral: Below clavicle in nipple line.

\section{CORRIGendum}

In an article by Kirk, Shield, Stenhouse, Bryce and Jakobowicz, Brit. J. prev. soc. Med. (1955), 9, 104, in the heading of Table VII on p. 108 for $\chi^{2}, \operatorname{read} \chi$. 